\title{
Explaining the Paucity of Intratumoral T Cells: A Construction Out of Known Entities
}

\author{
Douglas T. Fearon ${ }^{1,2,3}$ \\ ${ }^{1}$ Cold Spring Harbor Laboratory, Cold Spring Harbor, New York 11724 \\ ${ }^{2}$ Weill Cornell Medicine, New York City, New York 10065 \\ ${ }^{3}$ University of Cambridge, Cambridge CB2 1TN, United Kingdom \\ Correspondence:dfearon@cshl.edu
}

\begin{abstract}
This essay addresses the question of how tumors escape control by the immune system. The literature strongly points to inadequate accumulation of $\mathrm{T}$ cells among cancer cells as being the proximate cause, but this observation has no acceptable explanation as yet. An approach to this problem is adopted wherein the chemokines and chemokine receptors that normally mediate the trafficking of $\mathrm{T}$ cells to inflamed tissues are reviewed and considered in the context of their relative levels of expression in a transplanted colorectal tumor model. This method of reasoning - consistent with Bertrand Russell's (1985) advice, "Whenever possible, substitute constructions out of known entities for inferences to unknown entities"-leads to the proposal that signaling via the chemokine receptor, CXCR4, impairs the function of CXCR3 on the immune cells that are responsible for suppressing the growth of cancers.
\end{abstract}

The immune system has the capacity to control the growth of cancer. Clinical trials in which patients with certain types of solid tumors were administered neutralizing antibodies to membrane proteins that are expressed on activated effector and regulatory $\mathrm{T}$ cells, such as CTLA-4 and PD-1, or to PD-L1, the ligand for PD-1 that is expressed by some myelomonocytic cells and cancer cells, have shown that some patients show striking and often durable remissions (Hodi et al. 2010; Brahmer et al. 2012; Topalian et al. 2012; Hamid et al. 2013; Wolchok et al. 2013; Herbst et al. 2014; Powles et al. 2014; Tumeh et al. 2014; Motzer et al. 2015; Ferris et al. 2016). Other studies in which in vitro expanded tumor-infiltrating $\mathrm{T}$ cells have been adoptively transferred to cancer patients also have documented regressions of tumors (Tran et al. 2016). Finally, adoptive transfer of $T$ cells expressing chimeric antigen receptors, so-called CAR T cells, has been an effective therapy for CD19-expressing B-cell malignancies (Porter et al. 2011). Thus, as predicted by earlier studies, such as that showing better long-term outcomes in colorectal cancer patients whose tumors were characterized by " $\mathrm{CD} 8^{+} \mathrm{T}$ cells infiltrated within cancer cell nests" (Naito et al. 1998), the immune system, through the cytotoxic activities of the $\mathrm{CD} 8^{+} \mathrm{T}$ cell, has the capacity to kill immunogenic cancer cells. These successes present tumor immunologists with an urgent responsibility now to understand why only subsets of patients with only some types of cancers respond to these forms of immunotherapy. That is to say, "Why is immunotherapy ineffective in most patients?"

Potential contemporary answers to this question range from being self-evident, although nonetheless important, such as whether cancer cells have induced an adaptive immune response, to others for which mechanistic explanations are still evolving, such as T-cell "exhaustion" and immune inhibition by "myeloid-derived suppressor cells". Although the former can be definitively resolved by experimental approaches like the development of assays of anticancer T-cell immunity, the latter explanations will be more difficult to affirm or disprove. The complexity of the vertebrate immune system presents the tumor immunologist with almost too many experimental opportunities to "validate" hypotheses that may have conceptual rather than molecular definitions. More relevant to this question of tumoral immune escape is our knowledge that although the immune system evolved to defend against an extraordinary array of pathogens, it also developed "brakes" that prevent attack of semiallogeneic fetuses and autoimmune diseases. Namely, it is "normal" that the adaptive immune system may not always damage immunogenic tissue. For this reason, we should not assume that the capacity of an immunogenic tumor to escape immune control is a consequence of an abnormal immunological process, like a hostile tumor microenvironment (TME) causing "T-cell exhaustion." Instead, this unfortunate clinical circumstance may be explained by an immune pathway that benefits the host in biological circumstances other than cancer.

\section{T-CELL EXCLUSION-THE SHARED CHARACTERISTIC OF TUMORS ESCAPING IMMUNE CONTROL}

The most striking difference between a tissue immune reaction eliminates epithelial cells expressing immuno-

(C) 2016 Fearon. This article is distributed under the terms of the Creative Commons Attribution-NonCommercial License, which permits reuse and redistribution, except for commercial purposes, provided that the original author and source are credited. 
genic antigens, as in influenza virus-infected pulmonary epithelium, and an ineffective tumor immune reaction is the relative numbers of infiltrating $\mathrm{T}$ cells. Although informative and discerning metrics have been devised, such as "immunoscore" (Galon et al. 2016), and scientifically vague, but descriptive terms, such as "hot" and "cold" tumors, have been promoted to exemplify this difference, the most unambiguous characteristic of an immunologically uncontrolled tumor is the relative paucity of T cells that are juxtaposed to cancer cells (Joyce and Fearon 2015). In contrast, tumors that are being effectively eliminated by an immune response have dense infiltrates of $\mathrm{CD}^{+} \mathrm{T}$ cells, as do the islets of Langerhans of the pancreas in autoimmune type I diabetes mellitus, organs undergoing cell-mediated immune rejection, and, indeed, virally infected tissues, the last being a biological circumstance that selected this $\mathrm{CD}^{+} \mathrm{T}$-cell response. Therefore, if the relative intensity of the intratumoral accumulation of $\mathrm{CD}^{+} \mathrm{T}$ cells is the critical variable that distinguishes between effective and ineffective antitumor immune reactions, one should determine whether the principles that have been discovered to regulate these other examples of $\mathrm{CD}^{+}$T-cell accumulation also pertain to cancer. This approach would be consistent with the admonition of Bertrand Russell: "Whenever possible, substitute constructions out of known entities for inferences to unknown entities" (Russell 1985).

\section{THE NETWORK OF CHEMOKINE AND CHEMOKINE RECEPTORS: CXCR3 AS THE MEDIATOR OF INTRATUMORAL T-CELL ACCUMULATION}

We have known for many years that an extensive network of chemokines and chemokine receptors regulates the trafficking of immune cells (Griffith et al. 2014). The first chemokine receptor, which is thought to be CXCR4, appears in the jawless fish, lamprey, an ancient example of the vertebrate lineage in which the adaptive immune system that is typified by the $R A G$ genes is absent (Kuroda et al. 2003). With the further evolution of vertebrates, there is an explosion of chemokines and chemokine receptors, such that the zebrafish has 63 genes encoding chemokines and 24 genes encoding chemokine receptors (DeVries et al. 2006). The relevance of this system for directing the cellular migration is not limited to the immune system and is essential also for the development of many organs. However, in the postnatal period, the primary role of this system may well be immunological. The cells of the immune system most often mediate their effector functions in tissues that are remote from their sites of development and residence, the bone marrow, thymus, and secondary lymphoid organs. With respect to the effector $\mathrm{CD}^{+} \mathrm{T}$ cell, a remarkably consistent model has been developed. After their initial clonal expansion in secondary lymphoid organs, effector $\mathrm{CD}^{+} \mathrm{T}$ cells are released into the peripheral blood. Although these effector cells up-regulate their expression of a number of chemokine receptors during differentiation from naïve to effector $\mathrm{CD}^{+} \mathrm{T}$ cell, a single receptor, CXCR3, appears to be most often responsible for mediating homing to sites of inflammation. These CXCR3-mediated $\mathrm{CD}^{+}$T-cell responses depend on the production in the inflamed tissues of the chemokines, CXCL9, CXCL10, and CXCL11, the levels of which are regulated by type I and type II interferon (IFN) (Griffith et al. 2014). A dominant role for CXCR3 in T-cell homing has been found for a range of biological circumstances in which target cells express major histocompatibility complex (MHC) class I/peptide complexes bearing neoepitopes, including allograft rejection (Seung et al. 2011), viral infections (Klein et al. 2005; Hsieh et al. 2006), autoimmunity (Frigerio et al. 2002), and cancer (Mikucki et al. 2015), the last example being especially relevant to the subject of this discourse. In the B16 mouse model of melanoma, CXCR3 was shown to have a nonredundant role in mediating the intratumoral accumulation of adoptively transferred, cancer-specific, effector $\mathrm{CD}^{+} \mathrm{T}$ cells, which resulted in control of tumor growth by two complementary approaches-use of $\mathrm{CD}^{+} \mathrm{T}$ cells in which the CXCR3 gene had been disabled and administration of neutralizing anti-CXCR3 antibody. Two other receptors, CCR2 and CCR5, did not support the intratumoral trafficking of $\mathrm{CD}^{+} \mathrm{T}$ cells in this experimental model, serving, in effect, as negative controls. Therefore, despite the multiplicity of chemokine receptors that an effector $\mathrm{CD}^{+} \mathrm{T}$ cell expresses, and regardless of a diversity of immunological tissue reactions, CXCR3 has a dominant, positive role in the trafficking of these cells. In this regard, it is interesting to note that other immune cell types that should be considered important for orchestrating an effective antitumor immune reaction- $\mathrm{TH} 1$ cells, the subset of dendritic cells (DCs) with antigen cross-presenting capability, and natural killer (NK) cells-also express CXCR3, whereas other cell types that may even have tissue protective functions, such as monocytes and macrophages, do not.

Because the response of the preclinical B16 melanoma mouse model to anti-CTLA-4 immunotherapy (Leach et al. 1996) has been predictive of clinical immunotherapeutic responses of human melanoma (Hodi et al. 2010), the absence of a clinical response and the paucity of intratumoral $\mathrm{T}$ cells in those cancers that do not respond to immunotherapy may be considered to be caused by an absence of signaling by CXCR3 on $\mathrm{CD}^{+} \mathrm{T}$ cells within the TME. This deficiency may have one obvious explanation, which would be insufficient level of intratumoral CXCL9, CXCL10, or CXCL11, the ligands for CXCR3, but a second explanation is also possible, which is that the TME impairs signaling by CXCR3. There is evidence in support of the first explanation with the finding of epigenetic silencing of CXCL9 and CXCL10 as a means by which a preclinical tumor model circumvents immune control (Peng et al. 2015). Epigenetic silencing of the expression of these chemokines has been proposed also as the mechanism by which the semiallogeneic fetus escapes rejection by the maternal adaptive immune response (Nancy et al. 2012). Moreover, the finding that the type I IFN response is necessary for immune control 
of immunogenic mouse tumors (Diamond et al. 2011; Fuertes et al. 2011) may be related to the capacity of this cytokine to induce the transcription of CXCL10. Thus, it is reasonable to propose that insufficient levels of the CXCR3-related chemokines account for the impaired intratumoral accumulation of $\mathrm{T}$ cells. However, there may also be evidence in support of impaired CXCR3 function on immune cells in the TME.

\section{IMPAIRED FUNCTION OF CXCR3 IN THE C26 COLORECTAL TUMOR MODEL}

The C26 tumor is a chemically induced, transplantable mouse colon carcinoma that has been used in studies of cancer-induced cachexia. Its origin as a mutagen-induced cancer may indicate that it expresses neoantigens for presentation via the MHC class I pathway when transplanted and grown in mice. Therefore, it may serve as an appropriate model to explore the mechanism of impaired intratumoral accumulation of cancer-specific $\mathrm{CD} 8^{+} \mathrm{T}$ cells. In our studies of cancer-induced cachexia, we found relatively high mRNA levels for CXCL9 and CXCL10 in analyses of transplanted C26 tumors (Flint et al. 2016), which indicated that these tumors had two elements of an antitumor immune response, immunogenicity and CXCR3-related chemokines, that might be anticipated to be sufficient for immune control tumor growth. However, control obviously does not happen and ectopic C26 tumors continue to grow in immunocompetent, syngeneic mice. To gain insight into the reasons for this escape from immune control, we performed RNA-seq on whole C26 tumors to assess the expression of genes that mark specific immune cell types (Table 1). The C26 tumor has abundant monocytes and/or macrophages, as exemplified by the high mRNA levels of CSF1R, ITGAM, and F4/80. In contrast, and assuming that the expression of each gene per cell is relatively equivalent, the frequency of T cells is only $1 \%-5 \%$ that of monocytes/macrophages, based on the low mRNA levels of CD3e, CD4, and CD8a. Also, the mRNA levels of BATF3, CD103, XCR1, $C L E C 9 a$, and FLT3, five genes expressed by the antigen crossing-presenting subset of DCs, are similarly low, as is the mRNA level for the gene, NCR1 (NKp46), that encodes a receptor that is uniquely expressed by NK cells. Therefore, in the $\mathrm{C} 26$ tumor, there is a relative paucity of precisely those immune cells that would be capable of
Table 1. Expression of genes denoting immune cell types in the C26 tumor

\begin{tabular}{|c|c|c|}
\hline Gene & Cell type & RPKM \\
\hline CSF1R & Mono, Mac & 2652 \\
\hline ITGAM & Mono, Mac & 2901 \\
\hline$F 4 / 80$ & Mac & 1427 \\
\hline CD3e & $\mathrm{T}$ cell & 33 \\
\hline CD4 & $\mathrm{T}$ cell & 69 \\
\hline FOXP3 & Treg cell & 14 \\
\hline$C D 8 a$ & $\mathrm{~T}$ cell, $\mathrm{BATF}^{+}{ }^{+} \mathrm{DC}$ & 117 \\
\hline BATF3 & $\mathrm{BATF}^{+}{ }^{+} \mathrm{DC}$ & 29 \\
\hline CD103 & $\mathrm{BATF}^{+}{ }^{+} \mathrm{DC}$ & 22 \\
\hline$X C R 1$ & $\mathrm{BATF}^{+}{ }^{+} \mathrm{DC}$ & 31 \\
\hline CLEC9a & $\mathrm{BATF}^{+}{ }^{+} \mathrm{DC}$ & 22 \\
\hline FLT3 & $\mathrm{BATF}^{+}{ }^{+} \mathrm{DC}$ & 15 \\
\hline NCRl & NK cell & 35 \\
\hline
\end{tabular}

RPKM, reads per kilobase of transcript per million mapped reads; Mono, monocyte; Mac, macrophage; Treg, T regulatory; DC, dendritic cell; NK, natural killer.

promoting the killing of cancer cells: CTLs, NK cells, and the subset of DCs that direct clonal expansion of cancerspecific $\mathrm{CD}^{+} \mathrm{T}$ cells within the draining lymph node and within the tumor itself.

An examination of the expression of chemokines and chemokine receptors in the $\mathrm{C} 26$ tumor reveals a pattern that could account for the marked difference in immune cell types that accumulate in the $\mathrm{C} 26$ tumor. The mRNA for CXCR4, which is expressed by all immune cell types, is relatively abundant, presumably reflecting the presence of monocytes and macrophages (Table 2). In accord with this surmise, the mRNA levels for CCR2 and CCR5, two chemokine receptors that are expressed by monocytes and macrophages, are high. In contrast, mRNA levels for CXCR3 are drastically lower. This finding is consistent with the presumed low frequency of $\mathrm{T}$ cells, BATF3 ${ }^{+}$ DCs, and NK cells in the C26 tumor because these three cell types, in contrast to monocytes and macrophages, express CXCR3. The paucity of CXCR3-expressing immune cells cannot be explained by low tumoral expression of the ligands for this receptor because the combined mRNA level of CXCL9, CXCL10, and CXCL11 is even higher than that of CCL2 mRNA, the ligand for CCR2. This circumstance, assuming that these transcripts are translated, excludes the possibility that the relative deficiency of CXCR3-expressing cells is secondary to low levels if the receptor's cognate chemokines. Indeed, if

Table 2. Expression of chemokine and chemokine receptor genes in the $\mathrm{C} 26$ tumor

\begin{tabular}{llcccr}
\hline Receptor & \multicolumn{1}{c}{ Cell types } & RPKM & Chemokine & RPKM & Chemokine-R/chemokine ratio \\
\hline CCR2 & Teff, Mono, Mac & 825 & CCL2 & 1125 & 0.7 \\
CCR5 & Teff, iNKT, NK, Mac, pDC & 1775 & CCL3 & 42 & 7.7 \\
& & & CCL4 & 55 & \\
& & & CCL5 & 133 & \\
CXCR3 & TH1, CTL, pDC, Batf3 ${ }^{+}$DC, iNKT, NK, ILC1 & \multirow{2}{*}{10} & CXCL9 & 1384 & \\
& & & CXCL10 & 473 & \\
& & & CXCL11 & 68 & 1.005 \\
CXCR4 & All & 308 & CXCL12 & 187 & 1.7 \\
\hline
\end{tabular}

RPKM, reads per kilobase of transcript per million mapped reads; Teff, effector T-cell; Mono, monocyte; Mac, macrophage; iNKT, invariant natural killer T; pDC, plasmacytoid dendritic cell; CTL, cytotoxic T lymphocyte. 
one calculates the ratio of the mRNA levels of each chemokine receptor to its associated chemokine(s) as a measure of the activity of the receptor, one finds that the function of CXCR3 may be $<1 \%$ that of CCR2 in the C26 tumor. This finding is compelling evidence in support of the possibility that the CXCR3-expressing cells may not accumulate in the $\mathrm{C} 26$ tumor even when CXCL9-11 are expressed and strongly suggests that some aspect of the TME impairs CXCR3 function and causes an intratumoral immune phenotype that is equivalent to that of B16 melanoma-bearing mice treated in which cancer-specific $\mathrm{CD} 8^{+} \mathrm{T}$ cells are lacking CXCR3.

\section{CXCR4 AS THE CHEMOKINE RECEPTOR THAT INHIBITS CXCR3}

By conforming to the philosophical axiom of Bertrand Russell and focusing on the "known entity" of the chemokine/chemokine receptor system, we have identified a disparity between the intratumoral mRNA levels of CXCR3 and its ligands that strongly suggests that the TME suppresses the function of this chemokine receptor. Again, we turn to the literature in seeking a potential explanation of how the TME might alter the function of CXCR3. A spontaneously immunogenic, autochthonous mouse model of pancreatic ductal adenocarcinoma (PDAC) (Hingorani et al. 2005) escapes immune control by excluding $\mathrm{T}$ cells from the vicinity of cancer cells (Feig et al. 2013). Several findings suggested the possibility that CXCR4, a chemokine receptor found on all immune cells, had a role in this T-cell exclusion phenomenon: Conditional depletion of the cancer-associated fibroblasts enabled T-cell-dependent suppression of tumor growth; the cancer-associated fibroblasts were the major, intratumoral cellular source of CXCL12, the ligand for CXCR4; and the PDAC cancer cells appeared to be "coated" with the chemokine, despite the absence of CXCL12 mRNA in these cells (Kraman et al. 2010; Feig et al. 2013). A potential immunosuppressive role for CXCR4 was assessed by treating PDAC-bearing mice with AMD3100, a small-molecule inhibitor of CXCR4. Within $24 \mathrm{~h}$ of treatment initiation, $\mathrm{T}$ cells had accumulated among cancer cells, and within $48 \mathrm{~h}$, in combination with a T-cell checkpoint antagonist, anti-PD-L1 antibody, to which mouse and human PDACs are consistently resistant, the mouse tumor volume had decreased by $15 \%$. If the many publications attesting to the inhibitory specificity of AMD3100 for CXCR4 are correct, and if this PDAC tumor model obeys the same, nonredundant requirement for CXCR3 expression and function by $\mathrm{CD}^{+} \mathrm{T}$ cells in the B16 mouse melanoma (Mikucki et al. 2015), one is led to the conclusion that CXCR4 signaling suppresses the intratumoral function of CXCR3 in mouse PDAC to mediate the exclusion of $\mathrm{T}$ cells. The finding that AMD3100 also led to immune control of an ectopic Lewis lung tumor expressing the antigen, ovalbumin (Feig et al. 2013), indicates that this conclusion is not restricted to mouse PDAC. (See Fig. 1.)
CXCR4 has several characteristics that distinguish it from the other leukocyte, Gai protein-coupled receptors (GPCRs) that mediate chemotaxis. An ortholog of CXCR4 exists in the lamprey (Kuroda et al. 2003), a member of the Agnatha class. Therefore, this chemokine receptor, uniquely among all chemokine receptors, evolved before the vertebrate adaptive immune system of immunoglobulin and T-cell receptors. CXCR4 and its CXCL12 ligand demonstrate the highest degree of evolutionary conservation when chemokines and chemokine receptor sequences of human, mouse, chicken, frog, zebrafish, and pufferfish are compared (DeVries et al. 2006). Furthermore, unlike other chemokine receptors, CXCR4 has important nonimmunological roles, such as in the development of neural (Zou et al. 1996; Chalasani et al. 2003; Haas and Gilmour 2006) and cardiovascular systems (Tachibana et al. 1998), germ cell migration (Knaut et al. 2003; Molyneaux et al. 2003), and hematopoiesis (Zou et al. 1996). These features have led some investigators to classify CXCR4 and its ligand, CXCL12, as having "homeostatic" functions, in contrast to the immune and inflammatory functions of the other leukocyte chemokine receptors. Seen from this perspective, it is reasonable to consider the role of CXCR4 in other organ systems to obtain hints concerning whether and how it may alter the function of CXCR3 on immune cells.

An early demonstration of CXCR4 signaling altering the function of another GPCR was the finding that the chemotactic activities of both the $\mu$ - and $\delta$-opioid GPCRs in several cell types were desensitized following activation of CXCR4 in the responding cells (Szabo et al. 2002). Interestingly, this study also found that pretreatment with CXCL12 followed by opioid administration into the periaqueductal gray matter of the brain increased a behavioral response to a painful stimulus, consistent with CXCR4 signaling suppressing opioid receptor signaling of a cellular response distinct from motility. This conclusion was confirmed and extended by the demonstration that CXCR4, CXCL12, and the $\mu$-opioid receptor were coexpressed by individual neurons in several regions of the brain areas (Heinisch et al. 2011). Moreover,

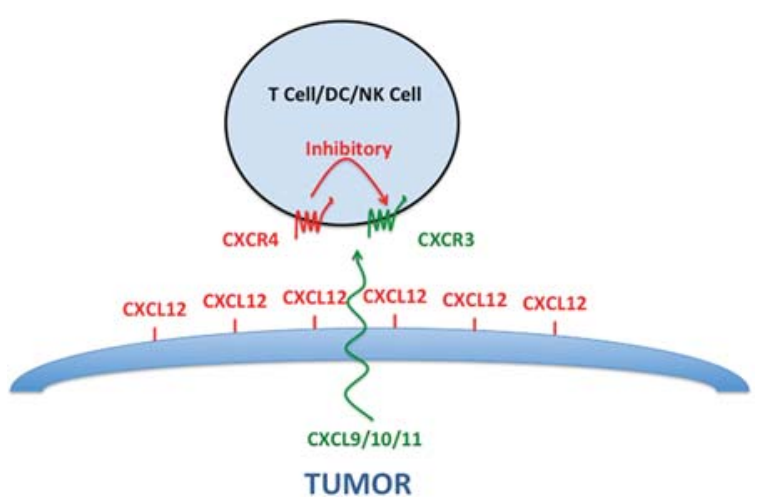

Figure 1. Proposed basis for the exclusion of T cells from tumors. CXCL12 "coats" tumor cells and stimulates CXCR4 on T cells, dendritic cells (DCs), and natural killer (NK) cells. CXCR4 then inhibits the capacity of CXCR3 to respond to tumor-derived CXCL9, CXCL10, and CXCL11. 
whole patch-clamp recordings of the periaqueductal grey neurons showed that CXCL12 blocked morphineinduced electrophysiological effects. This effect of CXCL12 was suppressed by AMD3100, demonstrating that it was mediated by CXCR4.

CXCR4 may mediate these inhibitory effects on opioid receptor function as a consequence of these two receptors forming heteromeric complexes (Stephens and Handel 2013). Therefore, in the context of this discourse on tumor immunity, it is of some interest that CXCR4 forms hetero-oligomeric complexes with CCR2 and CCR5 (Sohy et al. 2007, 2009). In the heterodimer formed between CXCR4 and CCR2, there is negative binding cooperativity between the subunits such that ligands that are specific for one receptor suppress the binding of the ligand to the other receptor. A similar negative binding cooperativity has been demonstrated for the chemokines interacting with heterodimers formed between CXCR4 and CCR5. The basis for such negative binding cooperativity was not determined but was suggested to be a consequence of allosteric modulation across the receptor heteromer interface. Although there is no evidence that CCR2 or CCR5 mediate the intratumoral accumulation of $\mathrm{T}$ cells, and, in fact, there is a report that CCR5 does not mediate this process (Mikucki et al. 2015), these findings do show the capacity of CXCL12 to cause CXCR4 to suppress the signaling by another chemokine receptor. In this respect, then, it may be relevant that CXCR4 and CXCR3 have been shown to form heteromeric complexes when ectopically expressed in HEK293T cells (Watts et al. 2013). Negative binding cooperativity between CXCR4 and CXCR3, however, was not observed in intact HEK293T cells, although the analysis was not performed with cells that normally express these two receptors.

These studies of the interaction of ligands with CXCR4-CCR2-CCR5 chemokine receptor heteromers also revealed that the effects of inhibitors of CXCR4 are more complex than has been concluded based on standard experiments using cells expressing only single types of chemokine receptors. For example, treatment of cells expressing only CCR2 with the CXCR4 antagonist, AMD3100, does not affect the binding of CCL2, and treating cells expressing only CXCR4 inhibits binding of CXCL12. With cells expressing CXCR4 in addition to CCR2, however, AMD3100 treatment suppresses not only binding of CXCL12 to CXCR4, but also that of CCL2 to CCR2 (Sohy et al. 2009). Similarly, AMD3100 does not alter the binding of CCL4 to cells expressing only CCR5, but the CXCR4 antagonist does alter the kinetics of the interaction between CCR5 and CCL4 with cells that also express CXCR4. These effects, which may be secondary to the partial agonistic activity of AMD3100 on CXCR4 (Zhang et al. 2002), emphasize the necessity to conduct in vitro experiments that reflect at least some aspects of the realities of in vivo biologynamely, that cells rarely express only a single chemokine receptor. For example, populations of activated effector $\mathrm{CD}^{+} \mathrm{T}$ cells may express CCR2, CCR5, CXCR3, CXCR4, and CXCR6. Studies of chemokine receptor antagonists must determine which inhibitors are truly "spe- cific" for their target receptor and do not alter the function of potential heteromeric partners.

Finally, CXCL12, the ligand of CXCR4, also shows a complexity that distinguishes it from other chemokines, especially with respect to the form in which it is present in carcinomas. In the autochthonous mouse model of PDAC, cancer cells stain with anti-CXCL12 (Feig et al. 2013). This staining with anti-CXCL12 of cancer cells has been reported also for human ovarian cancer (Scotton et al. 2002; Jiang et al. 2006), colorectal cancer (Akishima-Fukasawa et al. 2009), and PDAC (Liang et al. 2010), and we have observed it in mouse and human non-small cell lung cancer (NSCLC). These observations may be relevant to the means by which these cancers escape immune control because they are all characterized by exclusion of $\mathrm{T}$ cells from the vicinity of cancer cells (Naito et al. 1998; Zhang et al. 2003; Salmon et al. 2012; Feig et al. 2013) except for relatively infrequent examples of NSCLC and colorectal cancer that are associated with a high somatic mutational burden (Le et al. 2015; Rizvi et al. 2015). The means by which CXCL12 associates with cancer cells is not known, but it is reasonable to consider the possibility that this cell surface CXCL12 will be presented to CXCR4-expressing cells in a multimeric form rather than the monomeric form that is typically used in in vitro studies. Recent studies suggest that monomeric CXCL12 may not be the only or even most prevalent form of the chemokine. For example, dimeric CXCL12 is induced by the interaction of monomeric CXCL12 with negatively charged glycosaminoglycans (Veldkamp et al. 2005), which are a ubiquitous constituent of the TME. Dimeric CXCL12, in contrast to monomeric CXCL12, has been found to be resistant to proteolytic inactivation (Takekoshi et al. 2012), suggesting a means by which the half-life of the chemokine may be extended in a tissue-specific manner. Furthermore, dimeric CXCL12 elicits CXCR4-dependent $\mathrm{Ca}^{2+}$ flux, adenylyl cyclase inhibition, and activation of ERK1/2, but not chemotaxis (Drury et al. 2011). The interaction of dimeric CXCL12 with CXCR4 is also influenced by posttranslational sulfation of extracellular tyrosines (Veldkamp et al. 2006, 2008; Seibert et al. 2008). Thus, the physical state of CXCL12 may be dictated by the TME, and this may be an additional way that a tumor determines the type of intracellular signals that are elicited by CXCR4, adding an additional element of biological flexibility to this unusual chemokine/chemokine receptor system.

\section{CONCLUSION}

Immunogenic carcinomas escape immune control by creating a microenvironment that prevents the accumulation of T cells, DCs, and NK cells. Signaling by CXCR3 may usually mediate the accumulation of these immune cell types in tissue responses associated with the killing of cells expressing antigens, suggesting that the relative absence of these immune cell types in tumors is secondary either to a deficiency of the CXCR3-associated chemo- 
kines or to the malfunction of the chemokine receptor. An example is presented of a TME in which there is abundant expression of the CXCR3-associated chemokines, CXCL9, CXCL10, and CXCL11, but a relative paucity of T cells, DCs, and NK cells. The absence of CXCR3-expresssing immune cells in this tumor, then, must be secondary to inhibition of CXCR3 function. Because suppressing signaling by CXCR4 leads to intratumoral accumulation of $\mathrm{T}$ cells in this and other tumor models, because CXCL12 is present in tumors, and because the depletion of the intratumoral stromal cells that produce CXCL12 leads to control of tumor growth, one may reason that CXCR4 is responsible for the inhibition of CXCR3 function. This inhibition may be mediated through a physical association of CXCR4 with CXCR3 because ligation of CXCR4 in heteromeric complexes containing another GPCR may inhibit the function of the partner chemokine receptor. This type of crossdesensitization may occur also with CXCR4 "antagonists" that have partial agonistic activity, which may compromise the therapeutic efficacy of these antagonists in overcoming CXCR4-mediated restriction on the intratumoral accumulation of $\mathrm{T}$ cells.

This essay opened with a quote from Bertrand Russell and, in closing, one is reminded of another comment from this philosopher/mathematician: "The method of 'postulating' what we want has many advantages; they are the same as the advantages of theft over honest toil. Let us leave them to others and proceed with our honest toil" (Russell 1919). "Honest toil" in this essay refers to the experiments that have been performed by many thoughtful scientists whose experiments have provided the careful measurements of biological reactions that have enabled "constructions of known entities." Whether the author has deviated too far in the direction of "postulating" what he "wants" is a question that, thankfully, can be answered by experimentation.

\section{ACKNOWLEDGMENTS}

The author and his laboratory are supported by the Lustgarten Foundation. The author is grateful to his postdoctoral fellows and $\mathrm{PhD}$ students who, over the years, have enthusiastically taken on the difficult and rewarding challenges that immunology provides.

\section{REFERENCES}

Akishima-Fukasawa Y, Nakanishi Y, Ino Y, Moriya Y, Kanai Y, Hirohashi S. 2009. Prognostic significance of CXCL12 expression in patients with colorectal carcinoma. Am J Clin Pathol 132: 202-210.

Brahmer JR, Tykodi SS, Chow LQ, Hwu WJ, Topalian SL, Hwu P, Drake CG, Camacho LH, Kauh J, Odunsi K, et al. 2012. Safety and activity of anti-PD-L1 antibody in patients with advanced cancer. $N$ Engl J Med 366: 2455-2465.

Chalasani SH, Sabelko KA, Sunshine MJ, Littman DR, Raper JA. 2003. A chemokine, SDF-1, reduces the effectiveness of multiple axonal repellents and is required for normal axon pathfinding. J Neurosci 23: 1360-1371.
DeVries ME, Kelvin AA, Xu L, Ran L, Robinson J, Kelvin DJ. 2006. Defining the origins and evolution of the chemokine/ chemokine receptor system. J Immunol 176: 401-415.

Diamond MS, Kinder M, Matsushita H, Mashayekhi M, Dunn GP, Archambault JM, Lee H, Arthur CD, White JM, Kalinke $\mathrm{U}$, et al. 2011. Type I interferon is selectively required by dendritic cells for immune rejection of tumors. $J$ Exp Med 208: 1989-2003.

Drury LJ, Ziarek JJ, Gravel S, Veldkamp CT, Takekoshi T, Hwang ST, Heveker N, Volkman BF, Dwinell MB. 2011. Monomeric and dimeric CXCL12 inhibit metastasis through distinct CXCR4 interactions and signaling pathways. Proc Natl Acad Sci 108: 17655-17660.

Feig C, Jones JO, Kraman M, Wells RJ, Deonarine A, Chan DS, Connell CM, Roberts EW, Zhao Q, Caballero OL, et al. 2013. Targeting CXCL12 from FAP-expressing carcinomaassociated fibroblasts synergizes with anti-PD-L1 immunotherapy in pancreatic cancer. Proc Natl Acad Sci 110: 20212 20217.

Ferris RL, Blumenschein G Jr, Fayette J, Guigay J, Colevas AD, Licitra L, Harrington K, Kasper S, Vokes EE, Even C, et al. 2016. Nivolumab for recurrent squamous-cell carcinoma of the head and neck. N Engl J Med 375: 1856-1867.

Flint TR, Janowitz T, Connell CM, Roberts EW, Denton AE, Coll AP, Jodrell DI, Fearon DT. 2016. Tumor-induced IL-6 reprograms host metabolism to suppress anti-tumor immunity. Cell Metab 24: 672-684.

Frigerio S, Junt T, Lu B, Gerard C, Zumsteg U, Holländer GA, Piali L. 2002. $\beta$ cells are responsible for CXCR3-mediated Tcell infiltration in insulitis. Nat Med 8: 1414-1420.

Fuertes MB, Kacha AK, Kline J, Woo SR, Kranz DM, Murphy KM, Gajewski TF. 2011. Host type I IFN signals are required for antitumor $\mathrm{CD}^{+} \mathrm{T}$ cell responses through $\mathrm{CD} 8 \alpha^{+}$dendritic cells. J Exp Med 208: 2005-2016.

Galon J, Fox BA, Bifulco CB, Masucci G, Rau T, Botti G, Marincola FM, Ciliberto G, Pages F, Ascierto PA, et al. 2016. Immunoscore and Immunoprofiling in cancer: An update from the melanoma and immunotherapy bridge 2015. $J$ Transl Med 14: 273-279.

Griffith JW, Sokol CL, Luster AD. 2014. Chemokines and chemokine receptors: Positioning cells for host defense and immunity. Annu Rev Immunol 32: 659-702.

Haas P, Gilmour D. 2006. Chemokine signaling mediates selforganizing tissue migration in the zebrafish lateral line. Dev Cell 10: 673-680.

Hamid O, Robert C, Daud A, Hodi FS, Hwu WJ, Kefford R, Wolchok JD, Hersey P, Joseph RW, Weber JS, et al. 2013. Safety and tumor responses with lambrolizumab (anti-PD-1) in melanoma. $N$ Engl J Med 369: 134-144.

Heinisch S, Palma J, Kirby LG. 2011. Interactions between chemokine and $\mu$-opioid receptors: Anatomical findings and electrophysiological studies in the rat periaqueductal grey. Brain Behav Immun 25: 360-372.

Herbst RS, Soria JC, Kowanetz M, Fine GD, Hamid O, Gordon MS, Sosman JA, McDermott DF, Powderly JD, Gettinger SN, et al. 2014. Predictive correlates of response to the anti-PD-L1 antibody MPDL3280A in cancer patients. Nature 515: $563-$ 567.

Hingorani SR, Wang L, Multani AS, Combs C, Deramaudt TB, Hruban RH, Rustgi AK, Chang S, Tuveson DA. 2005. Trp53R172H and KrasG12D cooperate to promote chromosomal instability and widely metastatic pancreatic ductal adenocarcinoma in mice. Cancer Cell 7: 469-483.

Hodi FS, O'Day SJ, McDermott DF, Weber RW, Sosman JA, Haanen JB, Gonzalez R, Robert C, Schadendorf D, Hassel JC, et al. 2010. Improved survival with ipilimumab in patients with metastatic melanoma. $N$ Engl J Med 363: 711-723.

Hsieh MF, Lai SL, Chen JP, Sung JM, Lin YL, Wu-Hsieh BA, Gerard C, Luster A, Liao F. 2006. Both CXCR3 and CXCL10/IFN-inducible protein 10 are required for resistance to primary infection by dengue virus. J Immunol 177: $1855-$ 1863. 
Jiang YP, Wu XH, Shi B, Wu WX, Yin GR. 2006. Expression of chemokine CXCL12 and its receptor CXCR4 in human epithelial ovarian cancer: An independent prognostic factor for tumor progression. Gynecol Oncol 103: 226-233.

Joyce JA, Fearon DT. 2015. T cell exclusion, immune privilege, and the tumor microenvironment. Science 348: 74-80.

Klein RS, Lin E, Zhang B, Luster AD, Tollett J, Samuel MA, Engle M, Diamond MS. 2005. Neuronal CXCL10 directs $\mathrm{CD}^{+} \mathrm{T}$-cell recruitment and control of West Nile virus encephalitis. J Virol 79: 11457-11466.

Knaut H, Werz C, Geisler R, Nüsslein-Volhard C; Tübingen 2000 Screen Consortium. 2003. A zebrafish homologue of the chemokine receptor Cxcr4 is a germ-cell guidance receptor. Nature 421: 279-282.

Kraman M, Bambrough PJ, Arnold JN, Roberts EW, Magiera L, Jones JO, Gopinathan A, Tuveson DA, Fearon DT. 2010 Suppression of antitumor immunity by stromal cells expressing fibroblast activation protein- $\alpha$. Science 330: 827-830.

Kuroda N, Uinuk-ool TS, Sato A, Samonte IE, Figueroa F, Mayer WE, Klein J. 2003. Identification of chemokines and a chemokine receptor in cichlid fish, shark, and lamprey. Immunogenetics 54: 884-895.

Le DT, Uram JN, Wang H, Bartlett BR, Kemberling H, Eyring AD, Skora AD, Luber BS, Azad NS, Laheru D, et al. 2015. PD-1 blockade in tumors with mismatch-repair deficiency. $N$ Engl J Med 372: 2509-2520.

Leach DR, Krummel MF, Allison JP. 1996. Enhancement of antitumor immunity by CTLA-4 blockade. Science 271: 1734-1736.

Liang JJ, Zhu S, Bruggeman R, Zaino RJ, Evans DB, Fleming JB, Gomez HF, Zander DS, Wang H. 2010. High levels of expression of human stromal cell-derived factor-1 are associated with worse prognosis in patients with stage II pancreatic ductal adenocarcinoma. Cancer Epidemiol Biomarkers Prev 19: $2598-2604$

Mikucki ME, Fisher DT, Matsuzaki J, Skitzki JJ, Gaulin NB, Muhitch JB, Ku AW, Frelinger JG, Odunsi K, Gajewski TF, et al. 2015. Non-redundant requirement for CXCR3 signalling during tumoricidal T-cell trafficking across tumour vascular checkpoints. Nat Commun 6: 7458-7472.

Molyneaux KA, Zinszner H, Kunwar PS, Schaible K, Stebler J, Sunshine MJ, O'Brien W, Raz E, Littman D, Wylie C, et al. 2003. The chemokine SDF1/CXCL12 and its receptor CXCR4 regulate mouse germ cell migration and survival. Development 130: 4279-4286.

Motzer RJ, Escudier B, McDermott DF, George S, Hammers HJ, Srinivas S, Tykodi SS, Sosman JA, Procopio G, Plimack ER, et al. 2015. Nivolumab versus everolimus in advanced renalcell carcinoma. $N$ Engl J Med 373: 1803-1813.

Naito Y, Saito K, Shiiba K, Ohuchi A, Saigenji K, Nagura H, Ohtani H. 1998. $\mathrm{CD}^{+}{ }^{-}$T cells infiltrated within cancer cell nests as a prognostic factor in human colorectal cancer. Cancer Res 58: 3491-3494.

Nancy P, Tagliani E, Tay CS, Asp P, Levy DE, Erlebacher A. 2012. Chemokine gene silencing in decidual stromal cells limits $\mathrm{T}$ cell access to the maternal-fetal interface. Science 336: $1317-1321$.

Peng D, Kryczek I, Nagarsheth N, Zhao L, Wei S, Wang W, Sun Y, Zhao E, Vatan L, Szeliga W, et al. 2015. Epigenetic silencing of TH1-type chemokines shapes tumour immunity and immunotherapy. Nature 527: 249-253.

Porter DL, Levine BL, Kalos M, Bagg A, June CH. 2011. Chimeric antigen receptor-modified T cells in chronic lymphoid leukemia. $N$ Engl J Med 365: 725-733.

Powles T, Eder JP, Fine GD, Braiteh FS, Loriot Y, Cruz C, Bellmunt J, Burris HA, Petrylak DP, Teng SL, et al. 2014. MPDL3280A (anti-PD-L1) treatment leads to clinical activity in metastatic bladder cancer. Nature 515: 558-562.

Rizvi NA, Hellmann MD, Snyder A, Kvistborg P, Makarov V, Havel JJ, Lee W, Yuan J, Wong P, Ho TS, et al. 2015. Cancer immunology. Mutational landscape determines sensitivity to PD-1 blockade in non-small cell lung cancer. Science 348: $124-128$.
Russell B. 1985. Logical atomism. In The philosophy of logical atomism (ed. Pears DF), pp. 157-234. Open Court, La Salle.

Salmon H, Franciszkiewicz K, Damotte D, Dieu-Nosjean MC, Validire P, Trautmann A, Mami-Chouaib F, Donnadieu E. 2012. Matrix architecture defines the preferential localization and migration of $\mathrm{T}$ cells into the stroma of human lung tumors. J Clin Invest 122: 899-910.

Scotton CJ, Wilson JL, Scott K, Stamp G, Wilbanks GD, Fricker S, Bridger G, Balkwill FR. 2002. Multiple actions of the chemokine CXCL12 on epithelial tumor cells in human ovarian cancer. Cancer Res 62: 5930-5938.

Seibert C, Veldkamp CT, Peterson FC, Chait BT, Volkman BF, Sakmar TP. 2008. Sequential tyrosine sulfation of CXCR4 by tyrosylprotein sulfotransferases. Biochemistry 47: 1125111262.

Seung E, Cho JL, Sparwasser T, Medoff BD, Luster AD. 2011. Inhibiting CXCR3-dependent $\mathrm{CD} 8^{+} \mathrm{T}$ cell trafficking enhances tolerance induction in a mouse model of lung rejection. J Immunol 186: 6830-6838.

Sohy D, Parmentier M, Springael JY. 2007. Allosteric transinhibition by specific antagonists in CCR2/CXCR4 heterodimers. J Biol Chem 282: 30062-30069.

Sohy D, Yano H, de Nadai P, Urizar E, Guillabert A, Javitch JA, Parmentier M, Springael JY. 2009. Hetero-oligomerization of CCR2, CCR5, and CXCR4 and the protean effects of "selective" antagonists. J Biol Chem 284: 31270-31279.

Stephens B, Handel TM. 2013. Chemokine receptor oligomerization and allostery. Prog Mol Biol Transl Sci 115: 375-420.

Szabo I, Chen XH, Xin L, Adler MW, Howard OM, Oppenheim JJ, Rogers TJ. 2002. Heterologous desensitization of opioid receptors by chemokines inhibits chemotaxis and enhances the perception of pain. Proc Natl Acad Sci 99: 10276-10281.

Tachibana K, Hirota S, Iizasa H, Yoshida H, Kawabata K, Kataoka Y, Kitamura Y, Matsushima K, Yoshida N, Nishikawa S, et al. 1998. The chemokine receptor CXCR4 is essential for vascularization of the gastrointestinal tract. Nature 393: $591-594$

Takekoshi T, Ziarek JJ, Volkman BF, Hwang ST. 2012. A locked, dimeric CXCL12 variant effectively inhibits pulmonary metastasis of CXCR4-expressing melanoma cells due to enhanced serum stability. Mol Cancer Ther 11: 2516-2525.

Topalian SL, Hodi FS, Brahmer JR, Gettinger SN, Smith DC, McDermott DF, Powderly JD, Carvajal RD, Sosman JA, Atkins MB, et al. 2012. Safety, activity, and immune correlates of anti-PD-1 antibody in cancer. $N$ Engl J Med 366: 24432454.

Tran E, Robbins PF, Lu YC, Prickett TD, Gartner JJ, Jia L, Pasetto A, Zheng Z, Ray S, Groh EM, et al. 2016. T-cell transfer therapy targeting mutant KRAS in cancer. $N$ Engl $J$ Med 375: 2255-2262.

Tumeh PC, Harview CL, Yearley JH, Shintaku IP, Taylor EJ, Robert L, Chmielowski B, Spasic M, Henry G, Ciobanu V, et al. 2014. PD-1 blockade induces responses by inhibiting adaptive immune resistance. Nature 515: 568-571.

Veldkamp CT, Peterson FC, Pelzek AJ, Volkman BF. 2005. The monomer-dimer equilibrium of stromal cell-derived factor-1 (CXCL 12) is altered by $\mathrm{pH}$, phosphate, sulfate, and heparin. Protein Sci 14: 1071-1081.

Veldkamp CT, Seibert C, Peterson FC, Sakmar TP, Volkman BF. 2006. Recognition of a CXCR4 sulfotyrosine by the chemokine stromal cell-derived factor- $1 \alpha$ (SDF-1 $\alpha /$ CXCL12). $J$ Mol Biol 359: 1400-1409.

Veldkamp CT, Seibert C, Peterson FC, De la Cruz NB, Haugner JCIII, Basnet H, Sakmar TP, Volkman BF. 2008. Structural basis of CXCR4 sulfotyrosine recognition by the chemokine SDF-1/CXCL12. Sci Signal 1: ra4.

Watts AO, van Lipzig MM, Jaeger WC, Seeber RM, van Zwam M, Vinet J, van der Lee MM, Siderius M, Zaman GJ, Boddeke $\mathrm{HW}$, et al. 2013. Identification and profiling of CXCR3CXCR4 chemokine receptor heteromer complexes. $\mathrm{Br} J$ Pharmacol 168: 1662-1674.

Wolchok JD, Kluger H, Callahan MK, Postow MA, Rizvi NA, Lesokhin AM, Segal NH, Ariyan CE, Gordon RA, Reed K, 


\section{FEARON}

et al. 2013. Nivolumab plus ipilimumab in advanced melanoma. N Engl J Med 369: 122-133.

Zhang WB, Navenot JM, Haribabu B, Tamamura H, Hiramatu K, Omagari A, Pei G, Manfredi JP, Fujii N, Broach JR, et al. 2002. A point mutation that confers constitutive activity to CXCR4 reveals that T140 is an inverse agonist and that AMD3100 and ALX40-4C are weak partial agonists. J Biol Chem 277: 24515-24521.
Zhang L, Conejo-Garcia JR, Katsaros D, Gimotty PA, Massobrio M, Regnani G, Makrigiannakis A, Gray H, Schlienger K, Liebman MN, et al. 2003. Intratumoral T cells, recurrence, and survival in epithelial ovarian cancer. $N$ Engl J Med 348: 203-213.

Zou YR, Kottmann AH, Kuroda M, Taniuchi I, Littman DR. 1996. Function of the chemokine receptor CXCR4 in haematopoiesis and in cerebellar development. Nature 393: 595-599. 


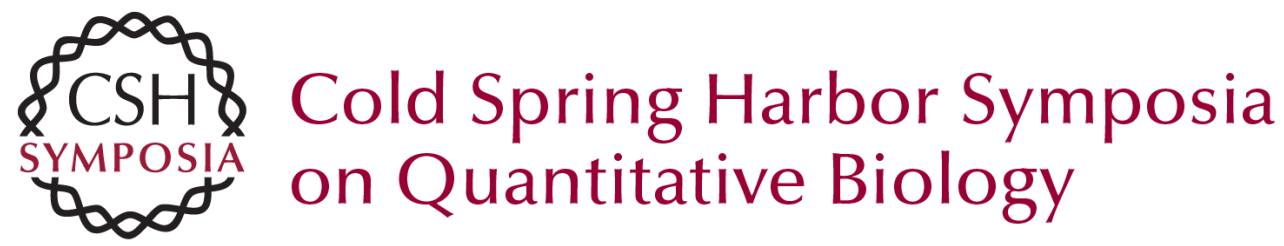

\section{Explaining the Paucity of Intratumoral T Cells: A Construction Out of Known Entities}

Douglas T. Fearon

Cold Spring Harb Symp Quant Biol 2016 81: 219-226 originally published online April 7, 2017 Access the most recent version at doi:10.1101/sqb.2016.81.030783

References This article cites 59 articles, 24 of which can be accessed free at: http://symposium.cshlp.org/content/81/219.full.html\#ref-list-1

Creative This article is distributed under the terms of the

Commons http://creativecommons.org/licenses/by-nc/4.0/, which permits reuse and License redistribution, except for commercial purposes, provided that the original author and source are credited.

Email Alerting Receive free email alerts when new articles cite this article - sign up in Service the box at the top right corner of the article or click here. 